\title{
Soviet aims in Southern Africa: Economic considerations
}

\author{
Lt C.M. Meyer*
}

\begin{abstract}
Introduction
While much has been said about the increasing involvement of the USSR in Southern Africa, little has been said about how and why the USSR wishes to achieve its aims in the sub-continent. Little has really changed since 1917 , when Lenin himself declared bluntly that the scientific concept of dictatorship means neither more nor less than unlimited power, resting directly on force, not limited by anything, nor restricted by any laws, nor any absolute rules. Nothing else but that. ${ }^{1}$
\end{abstract}

The increasing interest of the USSR in Southern Africa, the arms build-up in neighbouring countries, the better cadre of Soviet diplomats sent to the area: all this should be seen in the context that Soviet aims are essentially unchanged since 1917, and that the Kremlin wishes to establish dictatorships in Southern Africa. The Soviet policy in Southern Africa rests directly on force, and that it is bound by no absolute rules, should surprise nobody but the naïve. That Soviet policy in the sub-continent has some apparent contradictions should also come as no surprise: bearing in mind that it is 'not limited by anything, nor restricted by any laws'. ${ }^{3}$

\section{Capitalist motives for communist activity}

The heightened Soviet interest in Southern Africa can be accounted for in economic terms: a driving force behind Soviet activity may also be a need to secure raw materials. ${ }^{4}$ The twentieth century is now witnessing a repetition of the 'scramble for Africa' that took place in the nineteenth century. Now, however, it is not powers such as France, Germany, Great Britain, and Belgium that are involved but the USSR.

The USSR is not Marxist in the true sense of the word, but Marxist-Leninist. There is a world of difference between Marxist-Leninist practice: between Marx's naïve, unworkable idealism, and Lenin's practical use of terror. The Kremlin uses Marxism as a 'theology' to justify its reign of terror over the Russian-dominated Soviet empire. ${ }^{5}$

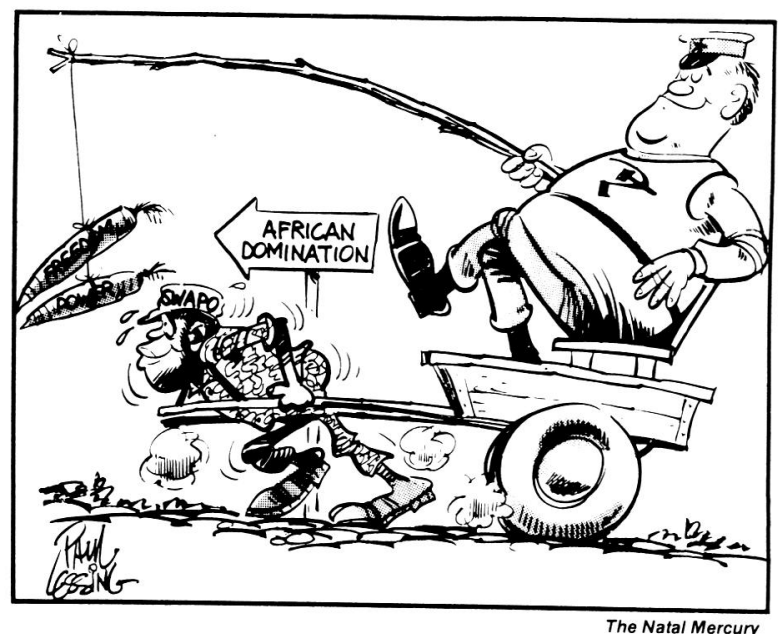

An artist's view of Soviet policy in Africa

'The bloody mire of Mongol slavery ... forms the cradle of Muscovy, and modern Russia is but a metamorphosis of Muscovy': these are the words of Karl Marx, ${ }^{6}$ again quoted by Richard Nixon on p. 56 of The Real War): Marx, the enemy of the Marxist state? It is doubly ironic that Marx's words are now just as apt in describing today the expansionist tendencies of the USSR, and the exploitation of Soviet workers:

Despite all the overwork, which continues throughout the day and the night, despite the most shameful underpayment of the workers, Russian manufacturing only manages to vegetate thanks to the prohibition of foreign competition. $^{7}$

(Capital: A Critique of Political Economy, Volume One, p. 703.) Communism depends on the continuing economic enslavement of workers by terror. Indeed, the military operations conducted by the USSR against Hungary in 1956, against Czechoslovakia in 1968, and against Afghanistan in 1980 may all be seen in this light: the need to prevent change, particularly economic change. The driving force behind the Soviet interventions in Hungary, Czechoslovakia, Afghanistan and also Poland has been fear; a fear of what would happen to the rest of the Soviet empire if one country were allowed to defect from it; a fear of what the rest of the Soviet empire would demand if one country were allowed more 
political freedom, more economic freedom, a higher standard of living. ${ }^{9}$ As Brezhnev said to Dubĉek shortly before the invasion of Czechoslovakia: 'Don't talk to me about socialism. What we (Russians) have we hold. ${ }^{10}$

While Soviet expansion can be seen as a systematic drive for world domination, it can also be seen as an inefficient system that can only survive by continued expansion. There are historical parallels. In the 19th century, Great Britain, France, Germany and other nations spent large amounts of their gross national products on defence. The burden of this defence spending was not felt in those countries, largely because the armies of those countries were put to very good use: in gaining new colonies. The raw materials obtained from these colonies meant another source of cheap imports (cheap because the power in control of the colony arranged the exports to suit itself, not the colony concerned), more factories and industries could be built to use the new cheap materials, and thus more economic growth resulted. ${ }^{11}$

In short, a vicious circle developed: bigger armies meant more colonies could be obtained, the economy grew, more could be spent on defence, still bigger armies and fleets resulted.

The growth of the Imperial powers of Europe and Russia was only ended by the First World Wara war caused by zones of influence expanding and becoming zones of competion for influence. ${ }^{12}$ Source: L.B. Russet, writing in International Affairs, Vol. 58, No. 1.

While an economy is on a war footing, the effects of high defence spending are not noticeable; if more colonies are being gained. But if the high level of defence spending is not put to 'good use', economic stagnation results. This may be seen in a comparison between the Great Britain of the nineteenth century, enjoying industrial growth and economic prosperity for much of that period; and the same country in the grim days of World War Two, a Great Britain where defence spending rose to $60 \%$ national product, a country with a war economy, with shortages and rationing everywhere in evidence. ${ }^{14}$ There is a country where defence spending consumes much of the gross national product, ${ }^{15}$ a country with a war economy, a country beset by shortages and economic stagnation: the USSR. Not only the USSR is in a state of deepening economic stagnation, but also the nations the USSR has conquered. One way out of this economic morass is to obtain economic colonies from where materials may be imported cheaply, not just for the USSR (blessed with a vast surfeit of raw materials), but also for Eastern Europe, which is unable to afford to import all the much-needed raw materials from the USSR. ${ }^{16}$

Thus, expansion in Africa suits the Kremlin two ways: more countries come under communist domination, the goal of world domination is advanced and the strategic goals of the Kremlin can thus be advanced. ${ }^{17}$ This is well known. But the communist strategy of world domination can also be advanced if Eastern European countries can exploit the raw materials of African countries: with this background, the presence of numerous Eastern European technicians in African countries takes on an added significance: while there are thousands of Cubans in Africa, most of the exploiting of natural resources is done by Eastern European technicians, engineers, etc. The extent of the investment of Eastern Europe in obtaining minerals is not often realised: 'East European companies in the developing world are worth nearly 4 billion, and all but eight per cent of their assets are tied up not in service, marketing and manufacturing but resource development such as mining. ${ }^{18}$

If communist countries are unable to compete effectively on the free market for raw materials, they will be forced to depend more and more upon other sources: colonies, especially colonies in Africa. This is illustrated by the following example: in a recent visit to Mozambique, the East German Minister of Mines advised that the Moatize coal mine should be nationalised. ${ }^{19}$ Such a step could give East Germany a supply of cheap coal - and cheap energy. Indeed, investment by communist countries such as Poland and East Germany has been heavy: so heavy that there is doubt as to whether either nation can afford to lose those investments. ${ }^{20}$ It comes as no surprise to learn that the Kremlin suggested to East European nations that they look to Africa as an alternate source of supply of minerals as early as 1956. The activities of the Soviets and their surrogates in Africa since 1956 can be viewed in two ways: as a strategy of denial, or as a strategy of gain. This is not a contradiction: what is denied to the West is gained to the East. Both theories are summarised below. 


\section{The strategy of denial}

The strategy of denial involves a denial of resources to the West, i.e. the aim is to place the USSR so as to be able to effectively threaten the movement of important resources to the West. This could take the form of interfering with shipping rounding the Cape carrying oil vital to Western economies. But such a strategy would also provide an explanation for Soviet interest in the Middle East, and Southern Africa: if the Kremlin were to obtain control of Middle Eastern oil, and the African countries producing strategic minerals such as chromite ore, cobalt and uranium, the USSR would be able to manipulate the Western economies virtually at will - in exchange for these vital raw materials. For example, nearly half of the uranium used by British nuclear reactions comes from the Rössing uranium mine in South-West Africa. The same mine provides about $17 \%$ of the non-commissioned world's uranium. ${ }^{24}$

The strategy of denial is usually seen in terms of Marxist-Leninist theory: Soviet activity in Africa and elsewhere is one more step on the long road towards world domination.

\section{The strategy of gain}

Here Soviet activity is viewed from an economic viewpoint: it is easier for the communists to obtain what they need from Africa than to exploit their own resources. In other words, the communist economic system is so hopelessly inefficient at exploiting the vast natural resources of the USSR and its satellites that it is far easier for the Soviet satellite nations to exploit the economies of Angola, Mozambique and other African nations than to import what they need for communist countries that are far nearer home. Poland exports coal and borders on East Germany. Yet East Germany is now interested in exploiting the Moatize coal mine in Mozambique as a source of coal: Mozambique is preferred to Poland as a source of coal!

In this strategy, communist expansion in Africa is undertaken not because of what Lenin said but more because the sheer inefficiency of the communist system demands it: Klaus Siebold did not visit Mozambique because Marxist-Leninism said he should, he went because East Germany was desperately in need of cheap energy and raw materials. ${ }^{25}$ The virtual brankruptcy of much of Eastern Europe ties in well with the Soviet expansion into Africa: Soviet-controlled Cuban forces are used to effectively provide economic 'colonies' which can be exploited by East Germany, Poland, Czechoslovakia, Hungary, Bulgaria, Rumania and Yugoslavia. The presence of technicians, teachers and skilled personnel from these countries in many Southern African nations is surely no coincidence.

An example of the strategy of gain being applied would be as follows. Firstly, terrorist attacks would escalate into a prolonged guerrilla war: as is happening in El Salvador today. This guerrilla war would then further escalate into a civil war: viz, the Lebanon. From the ensuing chaos, a new government would be formed, a government formed from ex-terrorists. This is now the case in Nicaragua and many African countries. The new government would not be forced to adopt economic policies suitable to the Kremlin: economic aid would be offered from the Soviet bloc, and the terms of this aid would include recommendations that mines and industries of interest to the communist bloc arrive to run the nationalised industries and mines as part of that aid. The output of these industries and mines can now be exported to either the USSR, or Eastern Europe: at very much cheaper prices than would normally be obtained. The country concerned is now under the virtual economic control of the Kremlin. ${ }^{27}$

\section{Conclusion}

A general description of the Soviet threat to Southern Africa has been given. Two aspects of this, the strategy of gain and the strategy of denial, have been expounded. However, it should never be forgotten that communist strategy is immutable: it is not changed by changing governments, by detente, or negotiations. When peace negotiations are being undertaken, it is essential to understand the Soviet view of peace: to impose communism is to attain peace, and true peace can only be attained when all the world is communist. ${ }^{28}$ To the Soviets, peace is a means of obtaining the goals of war by non-violent methods, peace is just another opportunity to regroup and improve the strategic position of the communist movement. ${ }^{28}$

\footnotetext{
References

1. Nixon, R., The Real War, New York, 1980, p. 254.

2. 'Soviet Policy in Southern Africa in 1982: some developments and considerations', Africa Insight, Vol. 12, No. 1, 1982, p. 17

3. The Real War, op. cit., p. 254.

4. Brownteld, A.C., The Growing United States Dependency on Imported Strategic Minerals, Foreign Affairs Research Institute, 2/1982, p. 6

5. Nixon, R., op. cit. p. 69 .

6. Nixon, R., op. cit. p. 56
} 
7. Karl Marx, Capital: A Critique of Political Economy, Vol. 1, Penguin Books, p. 703.

8. Barron, J., KGB: The Secret Work of Soviet Secret Agents, Corgi Books, London, 1979, p. 130.

9. Barber, N., Seven Days of Freedom: The Hungarian Uprising 1956, Macmillan, p. 146

10. Tucker, R.C., Swollen State, Spent Society: Stalin's Legacy to Brezhnev's Russia, Foreign Affairs, Vol. 60, No. 2, p. 429

11. Russet, B., Security and the Resources Scramble: Will 1984 be like 1914?, International Aftairs, Vol. 58, No. 1, 1981-1982, p. 47.

12. Ibid, p. 46

13. Barron, J., op. cit., p. 131.

14. Russet, B., op. cit., p. 49

15. Barron. J., op. cit., p. 131

16. Brownteld, A.C., op. cit., p. 6

17. Rees, D., Afghanistan's Role in Soviet Strategy, Conflict Studies No. 118, Institute for the Study of Conflict, London, May 1980, D. 5
18. 'The United States and Southern Africa's Mineral Resources: The East European Dimension,' South Africa International, Vol. 13, No. 1, July 1982, p. 7

19. Ibid, p. 10

20. Ibid, p. 11

21. Ibid, p. 7

22. Barron, j., op. cit. p. 46

23. Russet, B., op. cit. p. 5.

24. Africa South of the Sahara 1983-1984, Thirteenth edition, Europa Publications Limited, p. 611.

25. Soviet Analyst, Vol. 11, №. 3, p. 5.

26. Brownfeld, A.C., op. cit. p. 7.

27. The Soviet Empire: Pressures and Strains, Institute for the Study of Conflict, London, January 1980, p. 56

28. Emerson Vermaak, J.A. \& Bax, H., The Soviet Concept of Peace, Strategic Review, Vol. 11, No. 4, Fall 1983, p. 65. 